\title{
Metabolism of the Stimulated Rat Spleen
}

\author{
I. FERROCHELATASE ACTIVITY AS \\ AN INDEX OF TISSUE ERYTHROPOIESIS
}

Abraham Mazur

From The New York Blood Center, New York 10021

\begin{abstract}
A B S T R A C T Assay of the enzyme ferrochelatase in marrow, liver, spleen, and red cells has been employed to assess the extent of erythropoietic stimulation in animals bearing the Walker 256 carcinosarcoma and in rats treated by administration of phenylhydrazine, cobalt chloride, human urinary erythropoietin, or chronic blood loss. In all instances, the spleen sustains the most marked increase of ferrochelatase activity, per gram of tissue. Spleen erythropoietic activity stimulation was confirmed by quantitative measurements in respiring slices of ${ }^{59} \mathrm{Fe}$ and ${ }^{14} \mathrm{C}$ incorporation into hemoglobin and ferritin. Increased spleen ferrochelatase activity in cobalt chloride-treated rats is prevented by actinomycin $D$, indicating that stimulated synthesis of the enzyme is associated with the metabolism of RNA.
\end{abstract}

\section{INTRODUCTION}

Erythroid cell differentiation in adult mammalian bone marrow is stimulated by procedures that result in the loss of red cells, e.g., chronic bleeding or administration of phenylhydrazine, or by injection of cobalt salts (1). It has been postulated that such stimulation occurs by a mechanism involving the action of erythropoietin, a protein that appears in the plasma, as a result of the liberation of an erythropoietic factor from the hypoxic kidney (2). Such procedures, including the administration of erythropoietin, also stimulate erythropoiesis in the spleen, a minor source of red cells in the normal adult mammal (3). Evidence for such stimulation is usually based on histological

Received for publication 28 March 1968 and in revised form 21 June 1968. examination or the measurement of incorporation of injected ${ }^{59} \mathrm{Fe}$ into the tissues (4). In addition, other splenic cells (reticuloendothelial cells) may hypertrophy, e.g., in response to phenylhydrazine administration (5).

Because the entire spleen is readily available, containing all of the cells characteristic of erythroid tissue, it offers a suitable tool for investigating metabolic regulatory activities in an adult mammalian tissue. The present study describes the use of an enzymatic assay of ferrochelatase (6) to follow the quantitative changes associated with erythropoietic stimulation in various tissues of the rat after treatment of the animals by a variety of procedures. This enzyme catalyzes the formation of heme from $\mathrm{Fe}^{+2}$ and protoporphyrin and is relatively abundant in cells associated with hemoglobin synthesis as well as in cells (liver) that synthesize other hemeproteins at a relatively rapid rate. The results of the present study demonstrate a more marked stimulation of ferrochelatase activity, per gram of tissue, in the spleen than in the bone marrow of the rat, and these results have been confirmed by in vitro studies of hemoglobin synthesis in the spleens of treated rats. Associated with stimulation of hemoglobin synthesis is an increased synthesis of ferritin. The usefulness of the spleen in studies of regulatory mechanisms is illustrated by findings of an apparent shunting of erythropoietic activity from the bone marrow to spleen in rats bearing the Walker 256 carcinosarcoma.

\section{METHODS}

Materials. Rats were Wistar strain CFN randombred females weighing $150-200 \mathrm{~g}$ from the Carworth 
Farms, New York. Serum-bound ${ }^{50} \mathrm{Fe}$ was prepared by incubating normal rat serum with ${ }^{50} \mathrm{Fe}$ was prepared by incubating normal rat serum with $\mathrm{SO}_{4}{ }^{50} \mathrm{Fe}$ (Abbott Laboratories, North Chicago, Ill.) for at least $1 \mathrm{hr}$ before its use. The amount of chemical iron added to the serum was far below that required to saturate its iron-binding capacity. Purified human urinary erythropoietin was a gift from The Erythropoietin Committee of The National Heart Institute, U. S. Public Health Service. Actinomycin D was a gift from Merck Sharp \& Dohme, West Point, $\mathrm{Pa}$. Protoporphyrin was purchased from the Mann Biochemical Co., New York. It was dissolved in $0.1 \mathrm{~N} \mathrm{NH}_{4} \mathrm{OH}$ and refrigerated.

Treatment of rats. Anaesthetized rats $(35 \mathrm{mg} / \mathrm{kg}$ of Nembutal intramuscularly) were bled from the tail into a warm heparin-saline solution to the extent of $2 \mathrm{ml} /$ day on each of 3 consecutive days and studied 1 day later. Rats were injected subcutaneously with $5 \mathrm{mg}$ of neutralized phenylhydrazine hydrochloride on each of 4 consecutive days and studied 3 days after the last injection. Rats received two intraperitoneal injections ( $5 \mathrm{U} /$ injection) of erythropoietin, on each of 3 consecutive days and studied 1 day later. Rats bearing the Walker tumor were prepared by the subcutaneous administration of a cell suspension of the tumor prepared from a donor rat, originally supplied by the Rye Laboratories of the Sloan-Kettering Institute for Cancer Research of New York. The animals were used before any necrosis of the tumor had occurred.

Rat hemoglobin. Crystalline rat hemoglobin was prepared from pooled red cells of normal rats. The red cells were washed several times with saline and lysed by the addition of excess distilled water. After standing in the refrigerator overnight, the crsytalline hemoglobin and red cell stroma were recovered by centrifugation and washed with cold water several times. Hemoglobin was extracted with $0.05 \mathrm{M}$ Tris- $\mathrm{HCl}$ buffer, $\mathrm{pH} 8.6-8.8$, containing $0.15 \mathrm{M} \mathrm{NaCl}$ and $0.5 \mathrm{mg} / \mathrm{ml}$ of reduced glutathione (GSH). The extract was clarified by high speed centrifugation and dialyzed overnight against a large volume of $0.05 \mathrm{~m}$ Tris- $\mathrm{HCl}$ buffer, $\mathrm{pH} \mathrm{7.0.} \mathrm{The} \mathrm{crystal-}$ line hemoglobin was recovered by centrifugation and dissolved in the Tris-NaCl-GSH buffer, $\mathrm{pH} 8.6-8.8$. It was converted to carboxyhemoglobin by passing carbon monoxide through the solution and stored in the frozen state until required.

When examined by vertical starch-gel electrophoresis at $\mathrm{pH} 8.6$, the hemoglobin solution yielded four or five components that gave positive reactions with the benzidine reagent. Of these components, two major fractions moved rapidly towards the anode, one minor component moved more slowly towards the cathode, and another moved equally slowly towards the anode. A fifth and minor component occurred only in a small proportion of CFN rats whose individual hemoglobins were examined. Various preparations of crystalline rat hemoglobin yielded optical density ratios for $280: 540 \mathrm{~m} \mu$ varying from 2.6 to 2.9 and were eluted as a single component from a column of G-100 Sephadex equilibrated with 0.05 м Tris- $\mathrm{HCl}$ buffer, $\mathrm{pH} 7.4$.
Hemoglobin was separated into heme and globin components by the method of Teale (7) at a pH below 2.0 in an atmosphere of nitrogen. Heme was assayed spectrophotometrically as pyridine hemochromogen (6) and globin by the procedure of Lowry, Rosenbrough, Farr, and Randall (8). Analysis of globin ${ }^{1}$ yielded a value of 40 moles of glycine per $64,000 \mathrm{~g}$ of globin.

Incubation of rat spleen slices. Thin slices $(0.5 \mathrm{~mm})$ of rat spleen were prepared by use of a Stadie slicer (Arthur H. Thomas Co., Philadelphia, Pa.) and washed in cold saline in a stream of oxygen. The saline, containing spleen cell fragments and trapped red cells, was removed by decantation and the slices washed in fresh cold saline in a stream of oxygen. $\frac{1}{2} \mathrm{~g}$ wet weight aliquots of pooled slices (blotted in a uniform manner on filter paper) were transferred to 50-ml Erlenmeyer flasks placed in ice. $5 \mathrm{ml}$ of Krebs-Ringer bicarbonate solution, previously equilibrated with a mixture of $95 \% \mathrm{O}_{2}-5 \% \mathrm{CO}_{2}$ was added, together with isotopic compounds. In all experiments spleen slices from control rats were compared at the same time with equal weights of slices from treated rats. After incubation in a water bath at $38^{\circ} \mathrm{C}$ in an atmosphere of $\mathrm{O}_{2}-\mathrm{CO}_{2}$, with gentle shaking for the required period of time, the spleen slices from each flask were quickly transferred to a gauze strip on a funnel and then washed thoroughly by centrifugation with chilled saline. The tissue was treated as described for each experiment.

Ferrochelatase activity determination. The activity of this enzyme (protohaem ferro-lyase, EC 4.99.1.1) in liver, bone marrow, and spleen was determined by a modification ofthe method of Porra and Jones' (6). $\frac{1}{2}-1$ $\mathrm{ml}$ of a 1:5 homogenate of liver or spleen, or of a homogenate prepared from the bone marrow aspirated from the two hind legs of a rat into $5 \mathrm{ml}$ of Ringerphosphate medium, $\mathrm{pH} 7.4$, was placed in the main compartment of a Thunberg tube, together with $0.2 \mathrm{ml}$ of a $10 \%$ solution of sodium deoxycholate, $0.1 \mathrm{ml}$ of a solution containing $20 \mathrm{~m} \mu$ moles of protoporphyrin, and $2.9-3.4 \mathrm{ml}$ of buffer. The hollow glass stopper contained $0.1 \mathrm{ml}$ of $0.5 \%$ neutralized ascorbic acid solution and $0.2 \mathrm{ml}$ of a solution containing $36 \mu \mathrm{g}$ of ferrous ammonium sulfate together with approximately $100,000 \mathrm{cpm}$ of $\mathrm{SO}_{4}{ }^{-5} \mathrm{Fe}$. After evacuation of the tube by means of a pump, and equilibration in a water bath at $38^{\circ} \mathrm{C}$, the contents of the stopper were mixed with the solution in the main compartment of the tube and the mixture incubated at $38^{\circ} \mathrm{C}$ for $\frac{1}{2} \mathrm{hr}$. The reaction was stopped by the addition of $10 \mathrm{ml}$ of an acetone: glacial acetic acid (3:1) mixture. The suspension was heated to boiling in a water bath, and excess acetone was added to precipitate the proteins completely. After addition of $20 \mathrm{mg}$ of carrier hemin dissolved in pyridine-chloroform, the mixture was filtered and the residue washed with acetone. The acetone was removed in vacuo from the clear filterate and the residue added to $4 \mathrm{ml}$ of a $2 \%$ solution of strontium chloride in glacial acetic acid. Crystalline hemin was recovered as

${ }^{1}$ Dr. Kenneth Woods, The New York Blood Center, provided the quantitative amino acid analyses of rat globin. 
described by Labbe and Nashida (9). Spectrophotometric assay of the hemin solution permitted a correction for hemin lost during the isolation procedure. ${ }^{59} \mathrm{Fe}$ was estimated in a crystal scintillation counter.

Preliminary experiments designed to achieve a purification of the enzyme revealed a requirement for phospholipid in order to obtain full enzyme activity. This is illustrated by the loss of $56 \%$ of the ferrochelatase activity of a rat reticulocyte extract prepared with Tween 20 (Atlas Chemical Industries Inc., Wilmington, Del.), as the result of extensive dialysis, and the recovery of this activity by addition of egg yolk lecithin in the form of a dispersion prepared by ultrasonic vibration. Purification of the lecithin by silica-gel chromatography (10) led to recovery of the active material in the phosphatidylcholine fraction. This result is in agreement with that reported by Yoshikawa and Yoneyama (11) for duck erythrocyte stroma but differs from the results of Mazanowska, Neuberger, and Tait (12) who reported a specific requirement for phosphatidic acid for the enzyme from liver mitochondria.

Ferrochelatase activity, as measured by the method described earlier, was linear with time up to $1 \mathrm{hr}$, and all subsequent determinations were performed with an incubation time of $30 \mathrm{~min}$. At a concentration of $4 \mathrm{mg}$ of sodium deoxycholate per $\mathrm{ml}$, enzyme activity was proportional to tissue sample over the range from 0.2 to 2.0 $\mathrm{ml}$ of a 1:5 homogenate. However, in order to insure reliability of the results which compare tissues from control and treated animals, the same aliquots of a particular tissue were always employed, i.e., $1.0 \mathrm{ml}$ of a $1: 5$ spleen homogenate, $0.5 \mathrm{ml}$ of a $1: 5$ liver homogenate, $1.0 \mathrm{ml}$ of a homogenate containing the marrow aspirated from two hind legs of a rat (approximately $100 \mathrm{mg}$ wet

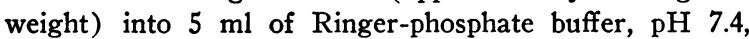
and $0.5 \mathrm{ml}$ of whole blood or washed red cells.

Since the tissues contained variable amounts of red cells sequestered from the circulation, and since such cells often include reticulocytes which contain ferrochelatase, the tissue enzyme activities were corrected by subtracting enzyme activity due to trapped cells. This was accomplished by determining the ferrochelatase activity of a sample of circulating red cells and estimating the total heme content of the tissue sample (as acid hematin), assuming that total tissue heme is due entirely to contamination with circulating red cells. However, it has been suggested that reticulocytes are "stickier" than normal cells (13), and they might be selectively trapped by the spleen, thereby contributing to the apparent increase in spleen ferrochelatase activity. In order to assess the extent of such reticulocyte sequestration, control and treated rats were injected intravenously with ${ }^{\circ} \mathrm{Fe}$ labeled reticulocytes prepared by injecting ${ }^{\circ 0} \mathrm{Fe}$ into several treated rats $24 \mathrm{hr}$ before removal of the cells. Since all treated rats had excessive reticulocytes in their circulation it would be expected that the ${ }^{59} \mathrm{Fe}$-labeled injected reticulocytes would be diluted by the unlabeled reticulocytes in the treated rats and thereby lead to a smaller uptake by their spleens than in control rats, pro- viding the treated rat spleens did not sequester much of the reticulocytes. When compared 1-4 $\mathrm{hr}$ after administration of ${ }^{50} \mathrm{Fe}$-labeled reticulocytes, treated rats contained the following amounts of ${ }^{60} \mathrm{Fe}$ per gram of spleen compared with control spleens, whose counts per minute are adjusted to 100 : phenylhydrazine, 32 ; cobalt chloride, 45 ; bled, 11 ; tumor, 38 . Although these data do not preclude some selective trapping of reticulocytes, they suggest that such trapping must be minimal.

Another possibility of an incorrect interpretation of observed increases in spleen ferrochelatase in treated rats arises from the fact that reticuloendothelial (RE) cells may increase, e.g., in phenylhydrazine rats, and that such cells may contain an excessive quantity of ferrochelatase. $\mathrm{RE}$ cells capable of ingesting very small particles of iron were prepared from the spleens of normal rats injected with such iron (14) and their ferrochelatase activity compared with that of the original spleen before removal of iron-laden $\mathrm{RE}$ cells. Per gram of protein, the activity of the original spleen was 2.5 times that of the iron-laden $\mathrm{RE}$ cells isolated from an aliquot of that spleen.

Ferrochelatase is associated with lipid-rich mitochondria or reticulocyte membranes, and addition of a lipiddispersing agent is necessary in order to solubilize the enzyme (15). We found that addition of the detergents deoxycholate or Tween 20 was necessary in order to recover maximum activity from tissue homogenates. The effectiveness of deoxycholate in releasing maximum enzyme activity varies with the particular tissue under examination, as well as with the kind of treatment to which the rat has been subjected. There is a greater increase in ferrochelatase activity, due to the addition of deoxycholate, from normal liver and marrow than from normal spleen, whereas the enzyme activity liberated by deoxycholate from the marrow of tumor-bearing rats is relatively greater than that liberated from normal marrow.

That ferrochelatase activity of blood samples is an index of the relative number of erythroid-active cells, e.g., nucleated erythroid cells and reticulocytes, is demonstrated by results of analyses of a reticulocyte-rich cell population in blood from phenylhydrazine-treated rabbits as well as of fractions of this blood prepared 2 by separation of the red cells by use of silicone fluids (16). The original cell suspension in silicone fluid $(75 \%$ reticulocytes) had an activity of $5062 \mathrm{cpm}$ of ${ }^{50} \mathrm{Fe}$ per mg of hemoglobin. The various fractions together with their reticulocyte counts were : 2103 (2\% reticulocytes) ; 11,751 (70\% reticulocytes) ; 22,214 (70\% reticulocytes); and 47,951 (>90\% reticulocytes). These data suggest that ferrochelatase activity is high in reticulocytes, although there is no direct relationship between reticulocyte count and ferrochelatase activity since not all reticulocytes contain the same amount of enzyme activity.

2 Drs. J. Goldstein and J. Christman, The New York Blood Center, provided the red cell fractions. 


\section{RESULTS}

Rat tissue ferrochelatase activity. Table I records the ferrochelatase activities per gram of tissue in treated rats compared with that of controls, the enzyme activities of the latter adjusted to 1.0. For marrow, results are expressed per milligram of total nitrogen which is a good index of total weight. For example, total nitrogen per milligram wet weight of marrow was found to be (average of three determinations): controls $28.5 \pm 0.9$; cobalt chloride injected $30.4 \pm 5.0$; and $29.3 \pm 2.7 \mathrm{mg}$ for tumor-bearing rats. The enzyme activity is markedly decreased in the marrow of tumor-bearing rats, is significantly increased in the marrow of rats treated with phenylhydrazine, is moderately increased in the marrow of other animals, and is markedly elevated in the spleen of all groups of treated animals. There were no changes in liver enzyme activity except in tumor-bearing rats. The marked increases in enzyme activity of circulating red cells may be equated with increases in numbers of reticulocytes, since adult red cells lack this enzyme.

That the stimulation of spleen ferrochelatase activity is not confined to young adult rats (150$180 \mathrm{~g}$ ) used in previous experiments is confirmed

TABLE I

Ferrochelatase Activity of Rat Tissues

\begin{tabular}{lcccc}
\hline Treatment & Marrow & Liver & Spleen & RBC \\
\hline Controls & $\begin{array}{c}1.0 \pm 0.2 \\
(2,972)\end{array}$ & $\begin{array}{c}1.0 \pm 0.4 \\
(94,000)\end{array}$ & $\begin{array}{c}1.0 \pm 0.3 \\
(18,550)\end{array}$ & $\begin{array}{c}1.0 \pm 0.2 \\
(21)\end{array}$ \\
$\begin{array}{c}\text { Tumor } \\
\text { Phenyl- } \\
\text { hydrazine }\end{array}$ & $1.7 \pm 0.3 \pm 0.2$ & $1.7 \pm 0.4$ & $1.6 \pm 0.1$ & $2.4 \pm 0.2$ \\
$\begin{array}{c}\text { Cobalt } \\
\text { chloride }\end{array}$ & $1.1 \pm 0.2$ & $0.8 \pm 0.1$ & $3.2 \pm 0.3$ & $5.7 \pm 0.4$ \\
$\begin{array}{c}\text { Blood loss } \\
\text { Erythro- } \\
\text { poietin }\end{array}$ & $1.4 \pm 0.2$ & $0.7 \pm 0.4$ & $4.3 \pm 0.487 .0 \pm 0.4$ \\
\hline
\end{tabular}

The results are expressed as the mean activity ( \pm standard deviation) of the enzyme in tissues from treated rats (six) compared with that in corresponding tissues of control animals, the latter adjusted to 1.0. Values in parentheses are actual mean counts per minute of heme- ${ }^{60} \mathrm{Fe}$ isolated from the enzyme assay tube per gram of liver or spleen, per milligram of marrow total $N$, and per milligram of hemoglobin in red cells, showing the relative activities of the enzyme in these tissues. by results obtained with older rats $(365 \mathrm{~g})$ treated with cobalt chloride. Relative enzyme activities per gram of tissue in these animals compared with control values adjusted to 1.0 , were : marrow 1.3 ; liver 0.8 ; spleen 3.3 ; and red cells 7.5 .

The stimulation of spleen ferrochelatase activity is not confined to the rat but may be demonstrated in the rabbit and guinea pig as well. The results of phenylhydrazine administration demonstrate that both rabbit marrow and spleen sustained marked increases in ferrochelatase activity as a result of phenylhydrazine administration: marrow 8.7; liver 1.2; spleen 4.5 ; and red blood cell 185 . Results for the guinea pig were comparable to those obtained for the rat. There was a significant increase in spleen weight in both groups of animals. Relative increases in spleen weight of treated rats were: controls 1.0 ; tumor 3.8 ; phenylhydrazine 4.0 ; bled 2.1 ; and erythropoietin 1.5. Spleens from cobalt chloride-injected rats did not increase in weight nor did the livers of any of the treated animals.

Histological examination ${ }^{3}$ of spleen sections revealed the presence of an increased number of nucleated erythroid cells in all treated rats as compared with spleens from control animals.

Hemoglobin synthesis in the spleens of normal and treated rats. Increased ferrochelatase activity in the spleens of treated rats is probably associated with a stimulation of erythroid cell differentiation, and therefore, with an increase in the number of cells capable of hemoglobin synthesis. The spleen from treated rats should therefore be an excellent tissue for the study of hemoglobin synthesis in vitro. Equal weights of spleen slices, from control and treated rats, were incubated with serum- ${ }^{59} \mathrm{Fe}$ or glycine $-{ }^{14} \mathrm{C}$, and excess isotope and loose cells were removed by washing with chilled saline. The tissue was homogenized, first with distilled water and then with $0.05 \mathrm{~m}$ Tris buffer, $\mathrm{pH} 7.0$, containing $0.15 \mathrm{M} \mathrm{NaCl}$ and centrifuged to yield a clear extract. The insoluble material was extracted once again with buffer, centrifuged, and the extracts were pooled. Carrier rat hemoglobin $(25 \mathrm{mg})$ dissolved in $0.05 \mathrm{M}$ Tris buffer $-0.15 \mathrm{M}$ $\mathrm{NaCl}, \mathrm{pH}$ 8.6, containing reduced $\mathrm{GSH}$, was

${ }^{3}$ Dr. Robert Hirsch, The New York Blood Center, examined and rated the histological sections of rat spleens. 

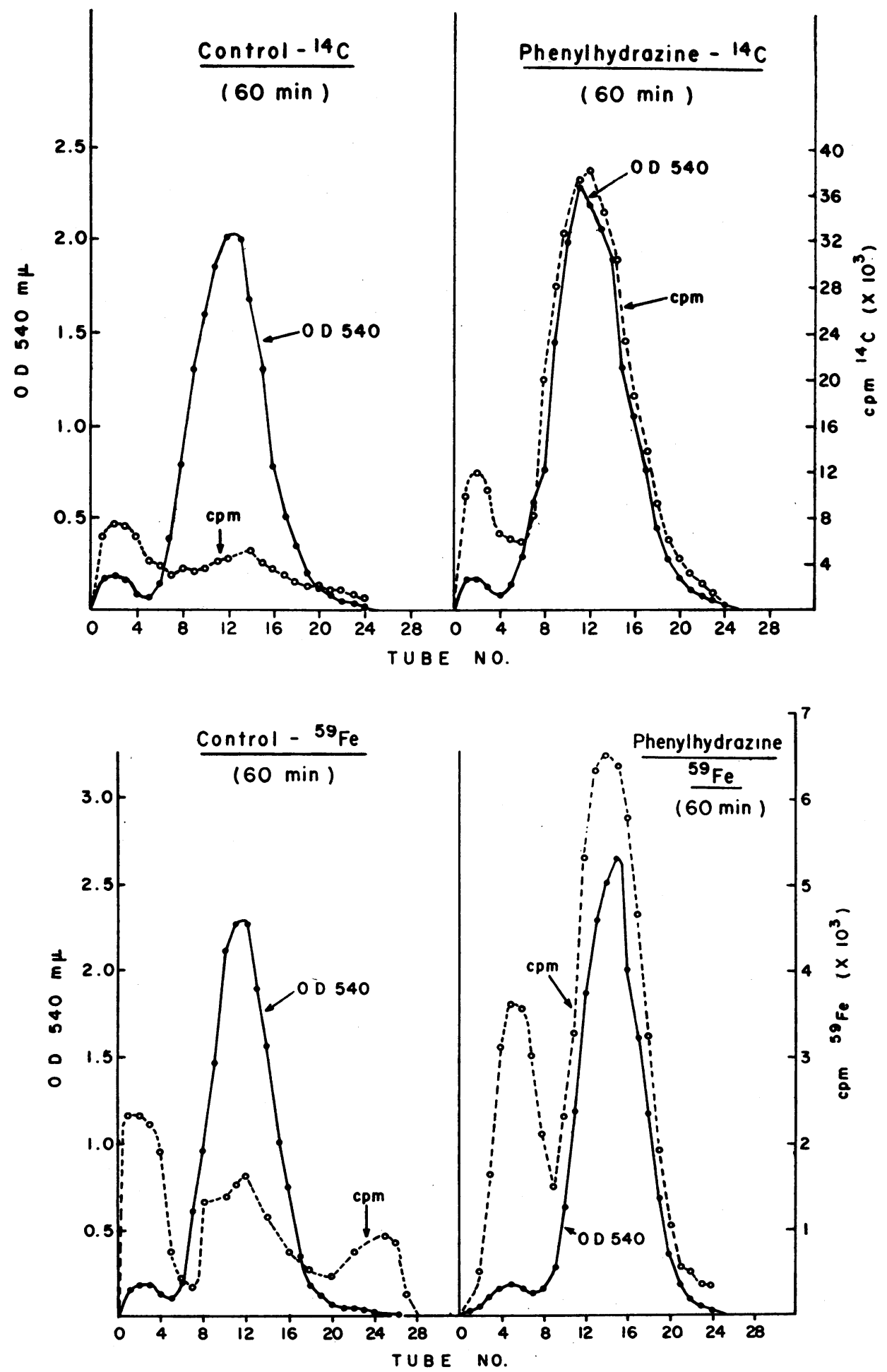

FIGURE 1 Sephadex G-100 filtration of extract containing hemoglobin from respiring spleen slices of control and phenylhydrazine-treated rats incubated with glycine- ${ }^{14} \mathrm{C}(a)$ or serum- ${ }^{50} \mathrm{Fe}$ (b) for $1 \mathrm{hr}$. 
added to each extract. The hemoglobin and other globulins of the spleen were precipitated in the cold at 0.5 saturation with ammonium sulfate, recovered by centrifugation, dissolved in $0.05 \mathrm{M}$ Tris buffer, $\mathrm{pH} 8.6,-0.15 \mathrm{M} \mathrm{NaCl}$ and reprecipitated with ammonium sulfate. The precipitate was dissolved in minimal quantities of the $\mathrm{pH} 8.6$ buffer containing GSH and dialyzed exhaustively against $0.05 \mathrm{~m}$ phosphate buffer, $\mathrm{pH} 7.0$, in the cold. The hemoglobin in the solution was recovered by centrifugation and any insoluble hemoglobin dissolved by extraction several times with the same buffer at room temperature to yield a total of $10 \mathrm{ml}$ of solution.

The solution, saturated with $\mathrm{CO}$, was placed on a $2 \times 30 \mathrm{~cm} \mathrm{G-100} \mathrm{Sephadex} \mathrm{column} \mathrm{equili-}$ brated with $0.05 \mathrm{M}$ phosphate buffer, $\mathrm{pH} 7.0$, at room temperature, and washed through the column with the same buffer. Fractions of $2.0 \mathrm{ml}$ were collected and optical densities at 280 and $540 \mathrm{~m} \mu$ recorded. Since the crystalline rat hemoglobin solutions had an optical density ratio of from 2.6-2.9, fractions corresponding to ratios below 3.0 were pooled for analysis of hemoglobin.

The fractions prepared from spleens of treated rats which were eluted before hemoglobin contained more ${ }^{59} \mathrm{Fe}$ or ${ }^{14} \mathrm{C}$ than comparable fractions obtained from spleens of untreated control rats (Fig. 1). These fractions were pooled from six experiments, the solution concentrated by dialysis against a concentrated solution of polyethylene glycol, and treated with an excess of rabbit anti-horse spleen ferritin serum. A precipitate formed that contained iron and protein in a ratio characteristic of the ferritin-antibody complex (17), and this precipitate contained some $5-10 \%$ of the total radioactivity of the pooled fractions.

Results of experiments in which spleen slices were incubated for varying periods of time with glycine-2-14 $\mathrm{C}$ indicated that incorporation of the isotope into both heme and globin was essentially linear for a period of $2 \mathrm{hr}$ (Fig. 2). Table II illustrates the calculated specific activities in heme and globin of the glycine incorporated into these fractions of the hemoglobin molecule during a $1 \mathrm{hr}$ incubation period. These were calculated by multiplying the counts per minute per milligram of heme by $650 / 8$ yielding counts per minute per millimole of glycine in heme, and by multiplying

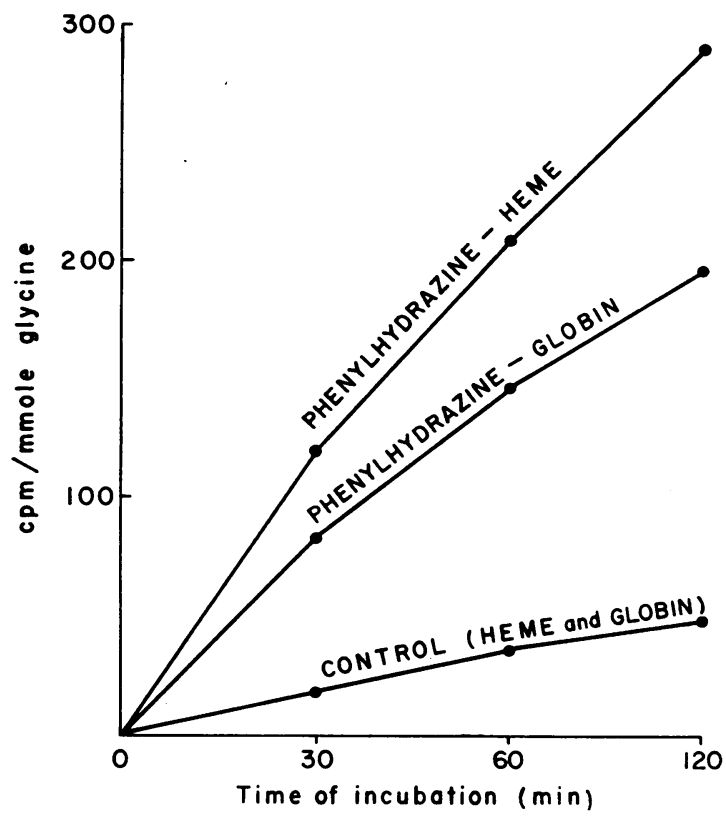

FIgURE 2 Time course of incorporation of glycine $-{ }^{14} \mathrm{C}$ into heme and globin of hemoglobin in spleen slices of control and phenylhydrazine-treated rats.

the counts per minute per milligram of globin by $64,000 / 40$ yielding counts per minute per millimole of glycine in globin (18). The data for hemoglobin synthesized by spleen slices in an atmosphere of $95 \% \quad \mathrm{O}_{2}$ reveal ratios of heme: globin of 1.0 for slices from control and bled rats, and somewhat higher ratios, 1.3 and 1.5 , for slices from rats injected with cobalt chloride and phenylhydrazine, respectively, although ratios as high as 2.5 were obtained in subsequent experiments.

In order to demonstrate that the incorporation of isotopes into hemoglobin in respiring spleen slices is associated with protein synthesis, the effects of added puromycin and chloramphenicol on incorporation of glycine- ${ }^{14} \mathrm{C}$ into heme and globin of hemoglobin was studied in spleen slices

TABLE II

Incorporation of Glycine-14C into Heme and Globin of Hemoglobin by Rat Spleen in Vitro in $95 \% \mathrm{O}_{2}$

\begin{tabular}{|c|c|c|c|}
\hline & \multicolumn{2}{|c|}{$\begin{array}{c}\mathrm{cpm} / \mathrm{mmole} \text { of glycine } \\
\times 10^{-5} \text { in }\end{array}$} & \multirow{2}{*}{$\frac{\text { Heme }}{\text { Globin }}$} \\
\hline & Heme & Globin & \\
\hline Control & 43.3 & 48.0 & 0.9 \\
\hline Bled & 228.0 & 224.8 & 1.0 \\
\hline Cobalt chloride & 211.4 & 159.8 & 1.3 \\
\hline Phenylhydrazine & 290.3 & 196.6 & 1.5 \\
\hline
\end{tabular}


from bled rats. At a concentration in the incubation medium of $50 \mu \mathrm{g} / \mathrm{ml}$ of puromycin, incorporation of the isotope into heme and globin of hemoglobin was inhibited to the extent of 59 and $53 \%$ respectively; at $100 \mu \mathrm{g} / \mathrm{ml}$, inhibition was 79 and $83 \%$ respectively. At a concentration of $250 \mu \mathrm{g} / \mathrm{ml}$ of chloramphenicol, the respective inhibitions were 41 and $40 \%$.

Table III compares the relative increase in extent of incorporation of ${ }^{59} \mathrm{Fe}$ with that of ${ }^{14} \mathrm{C}$ into the heme of hemoglobin by respiring rat spleen slices. The increase in ${ }^{50} \mathrm{Fe}$ incorporation due to phenylhydrazine administration was much greater than the increase of glycine- ${ }^{14} \mathrm{C}$. The reverse was true for bled rats or rats injected with cobalt chloride.

Incorporation of ${ }^{59} \mathrm{Fe}$ and glycine ${ }^{-14} \mathrm{C}$ into ferritin of respiring spleen slices. Equal weights of spleen slices $(0.5 \mathrm{~g})$ were incubated with serum${ }^{59} \mathrm{Fe}$ or glycine- ${ }^{14} \mathrm{C}$ for $1 \mathrm{hr}$, and ferritin was isolated by the method previously described (17), in the form of the specific antigen-antibody complex. The results in Table IV demonstrate a marked stimulation of isotope incorporation into spleen ferritin of the treated animals. However, ${ }^{59} \mathrm{Fe}$ incorporation was stimulated to a greater extent than that of glycine- ${ }^{14} \mathrm{C}$. Increases in isotope incorporation into liver ferritin were also noted, although these increases were less marked, per gram of tissue, than in the spleen, except for the liver from tumor-bearing rats, whose incorporation of glycine- ${ }^{14} \mathrm{C}$ into ferritin was stimulated to a greater extent than in the spleen. As was also observed in experiments measuring hemoglobin synthesis by spleen slices from bled rats, incorporation of glycine- ${ }^{14} \mathrm{C}$ into ferritin of spleen slices from cobalt chloride-treated rats was inhibited by puromycin (69\% at a level of inhibitor of 0.50

TABLE III

Comparison of ${ }^{59} \mathrm{Fe}$ and Glycine- ${ }^{14} \mathrm{C}$ Incorporation into Heme of Hemoglobin in Rat Spleen in Vitro in $95 \% \mathrm{O}_{2}$

\begin{tabular}{lcc}
\hline & \multicolumn{2}{c}{$\begin{array}{c}\text { Relative incorporation into } \\
\text { heme of }\end{array}$} \\
\cline { 2 - 3 } & Serum-69Fe & Glycine-14C \\
\hline Control & 1.0 & 1.0 \\
Bled & 2.9 & 6.5 \\
Cobalt chloride & 2.3 & 5.6 \\
Phenylhydrazine & 8.3 & 3.2 \\
\hline
\end{tabular}

TABLE IV

Incorporation of Serum ${ }^{59} \mathrm{Fe}$ and Glycine $-{ }^{14} \mathrm{C}$ into Ferritin of Respiring Rat Spleen and Liver

\begin{tabular}{lccccc}
\hline \multirow{2}{*}{ Treatment } & \multicolumn{2}{c}{ Spleen } & & \multicolumn{2}{c}{ Liver } \\
\cline { 2 - 3 } \cline { 5 - 6 } \cline { 5 - 6 } & ${ }^{59} \mathrm{Fe}$ & ${ }^{14} \mathrm{C}$ & & & \\
\hline Controls & 1.0 & 1.0 & & 1.0 & 1.0 \\
& $(7486)^{*}$ & $(6484)$ & & $(4640)$ & $(10,306)$ \\
Phenylhydrazine & 23.7 & 12.1 & & 3.0 & 2.7 \\
Cobalt chloride & 24.6 & 11.5 & & - & - \\
Blood loss & 24.9 & 4.6 & & 6.7 & 2.6 \\
Tumor & 9.7 & 2.7 & & 4.3 & 6.9 \\
\hline
\end{tabular}

* Values in parenthesis are counts per minute in the ferritin from $0.5 \mathrm{~g}$ of tissue slices.

$\mu \mathrm{g} / \mathrm{ml})$ and by chloramphenicol (38\% at a concentration of inhibitor of $250 \mu \mathrm{g} / \mathrm{ml}$ ).

Effect of actinomycin $D$. That the increased ferrochelatase activity observed in spleens from treated rats was associated with a stimulation of RNA metabolism was confirmed in vivo by a study of the effect of small doses of actinomycin $D$, an inhibitor of DNA-dependent RNA synthesis, on the ferrochelatase activity of cobalt chloride-injected rats. The results are shown in Table V. Actinomycin D $(10 \mu \mathrm{g} / 100 \mathrm{~g}$ of body weight) administered to normal rats on each of 3 successive days resulted in a moderate inhibition of enzyme activity of marrow and spleen and in a decrease in activity of this enzyme in circulating red cells, due to a decreased number of circulating reticulocytes. Actinomycin, administered to rats receiving cobalt chloride, eliminated the stimulation of spleen ferrochelatase observed in normal

\section{TABLE V}

Effect of Actinomycin D on Ferrochelatase Activity in Cobalt Chloride-Treated Rats

\begin{tabular}{lccc}
\hline & $\begin{array}{c}\text { Cobalt } \\
\text { chloride }\end{array}$ & $\begin{array}{c}\text { Actino- } \\
\text { mycin }\end{array}$ & $\begin{array}{c}\text { Actinomycin } \\
+ \text { cobalt } \\
\text { chloride }\end{array}$ \\
\hline & \multicolumn{2}{c}{ (Untreated controls $=1.0)$} \\
Liver wt & 1.1 & 0.8 & 0.8 \\
Spleen wt & 0.9 & 0.8 & 0.4 \\
Heme synthetase & & & \\
Marrow & 0.6 & 0.6 & 0.4 \\
Liver & 0.6 & 1.3 & 1.1 \\
Spleen & 2.2 & 0.6 & 0.6 \\
RBC & 3.6 & 0.1 & 0.8 \\
\hline
\end{tabular}

Rats received $10 \mu \mathrm{g}$ of actinomycin per $100 \mathrm{~g}$ body weight on each of 3 successive days. 
animals treated with cobalt chloride, and resulted in a more marked lowering of the enzyme activity in the marrow. This quantity of actinomycin (30 $\mu \mathrm{g}$ total) is lower than that $(70-150 \mu \mathrm{g})$ usually used to suppress RNA synthesis and the induction of liver enzymes or to significantly reduce general liver protein synthesis (19).

\section{DISCUSSION}

The results of the present study suggest that the adult rat spleen reacts most markedly, per gram of tissue, to a variety of erythropoietic stimulation procedures. Quantitative estimation of ferrochelatase activity in marrow, spleen, and circulating red cells of treated animals compared with untreated controls appears to provide a good index of the extent of changes in erythroid cell population. Although some sequestration of circulating reticulocytes by the spleen is not precluded by our experimental data, it is unlikely that such sequestration could account for the observed increases in spleen ferrochelatase activity. The use of washed spleen slices further reduces the possibility that the increases in rate of hemoglobin and ferritin synthesis noted in such studies is due to contamination by circulating reticulocytes. Since many of the spleens from treated rats sustain an increase in the number of RE cells, it is important to note that such cells do not contribute a large proportion of the total ferrochelatase activity in the spleen.

The demonstration of increased incorporation of ${ }^{59} \mathrm{Fe}$ and glycine- ${ }^{14} \mathrm{C}$ into both the hemoglobin and ferritin of spleen slices from treated rats confirms the usefulness of this tissue for studies of iron metabolism. Such in vitro studies can be done with adequate controls by use of an equal weight of spleen slices from untreated rats, the entire organ is available for sampling, and this tissue contains the full complement of cells as they exist in the intact organ. Their metabolic integrity is confirmed by the inhibition of protein synthesis by puromycin and chloramphenicol and by stimulation of the synthesis of RNA, DNA, and nuclear basic histones to be reported elsewhere.

Differences in the relative extent of incorporation of ${ }^{59} \mathrm{Fe}$ and glycine- ${ }^{14} \mathrm{C}$ into heme and globin of spleen slices from treated rats may be ascribed to changes in pool size, since the rate of incorporation of these isotopes is almost linear over a $2 \mathrm{hr}$ period of incubation. However, stimulation of ${ }^{59} \mathrm{Fe}$ incorporation into ferritin of spleen slices from treated rats was in all instances much greater than that of glycine- ${ }^{14} \mathrm{C}$, a fact which suggests a more specific stimulation of the iron incorporation reaction than of protein synthesis. This may result from an increased rate of oxidative metabolism, i.e. adenosine triphosphate (ATP) formation, which we have demonstrated to be responsible for the increased incorporation of iron into liver ferritin (20).

Our findings in rats bearing the Walker tumor are of interest since extramedullary erythropoietic stimulation in the spleen occurs under conditions which are associated with a marked depression in bone marrow erythropoietic activity, resulting in a mild anemia. The spleens of these animals synthesize both hemoglobin and ferritin at an increased rate. These results could explain the increased uptake of ${ }^{59} \mathrm{Fe}$ by the spleen of tumorbearing mice, reported by Hevesy and Lockner (21), and may be applicable to the observations made in human malignancies of an anemia not associated with blood loss (22) and to the reports of an increased quantity of total iron in their spleens (23). The origin of spleen erythropoietic stimulation in animals bearing the tumor may be ascribed to hypoxia resulting from loss of bone marrow erythropoietic activity, or to a shortened life span of the circulating erythrocytes (21). A similar shortened life span of red cells has been reported in animals after blood loss (24).

The preliminary data obtained with purified human erythropoietin indicate that it can mimic many of the effects noted in animals treated by other procedures, i.e., stimulation of incorporation of injected ${ }^{59} \mathrm{FE}$ into total tissue heme of the spleen was greater, per gram of tissue, than in liver or marrow, and there was a marked increase in ferrochelatase activity in the spleen. These results support the hypothesis that the various methods used to produce erythropoietic stimulation may do so by an erythropoietin-release mechanism. When taken together with the evidence presented by Jordan (25) that spleen or presplenic tissue is the major site of red cell production in the adult lower forms of vertebrates, and that erythropoietin stimulates differentiation of a "stem cell" precursor of erythrocytes, these results suggest that the spleen is an excellent tissue for the study of the role of nucleic acids in cellular differentiation. 


\section{ACKNOWLEDGMENTS}

The author is indebted to Sheryl Brooks and Richard

Kung for their able technical assistance.

This work was supported by grants HE 09011 from

The National Heart Institute, and T-464 from the American Cancer Society.

\section{REFERENCES}

1. Wintrobe, M. M. 1961. Clinical Hematology. Lea \& Febiger, Philadelphia. 5th edition.

2. Gordon, A. S. 1960. Humoral influences on blood cell formation and release. In Ciba Foundation symposium on haemopoiesis. G. E. W. Wolstenholme and M. O'Connor, editors. Little, Brown and Company, Boston. 328.

3. Nakao, K., F. Takaku, S. Fujioka, and S. Sassa. 1966. The effect of erythropoietin on hematopoietic organs of the polycythemic mouse. Blood. 27: 537; Rosse, W. F., T. A. Waldmann, and D. E. Houston. 1962. Erythropoietin assays using iron $^{\text {50 }}$ incorporation into blood and spleen of the polycythemic mouse. Proc. Soc. Exptl. Biol. Med. 109: 836; Rambach, W. A., H. L. Alt, and J. A. D. Cooper. 1957. The mode of action and nature of a heat stable plasma erythropoietic factor. Blood. 12: 1101.

4. Rambach, W. A., J. A. D. Cooper, and H. L. Alt. 1955. The uptake of radioiron in the bone marrow as a measure of erythropoiesis. Proc. Central Soc. Clin. Res. 28: 62.

5. Jacob, H. S., R. A. MacDonald, and J. H. Jandl. 1963. Regulation of spleen growth and sequestering function. J. Clin. Invest. 42: 1476; Azen, E. A., and R. F. Schilling. 1963. Role of the spleen in acetylphenylhydrazine (APH) anemia in rats. J. Lab. Clin. Med. 62: 59.

6. Porra, R. J., and O. T. G. Jones. 1963. Studies on ferrochelatase. I. Assay and properties of ferrochelatase from a pig-liver mitochondrial extract. Biochem. J. $87: 181$.

7. Teale, F. W. J. 1959. Cleavage of the haem-protein link by acid methylethylketone. Biochim. Biophys. Acta. 35: 543.

8. Lowry, O. H., N. J. Rosenbrough, A. L. Farr, and R. J. Randall. 1951. Protein measurement with Folin phenol reagent. J. Biol. Chem. 193: 265.

9. Labbe, R. F., and G. Nishida. 1957. A new method of hemin isolation. Biochim. Biophys. Acta. 26: 437.

10. Rhodes, D. N., and C. H. Lea. 1957. Phospholipids. On the composition of hen's egg phospholipids. Biochem. J. 65: 526.

11. Yoshikawa, H., and Y. Yoneyama. 1964. Incorporation of iron in haem moyiety. In Iron Metabolism. F. Gross, editor. Springer-Verlag, Berlin. 24.

12. Mazanowska, A. M., A. Neuberger, and G. H. Tait. 1966. Effect of lipids and organic solvents on the enzymic formation of zinc protoporphyrin and heme. Biochem. J. 98: 117.
13. Jandl, J. H. 1959. The agglutination and sequestration of immature red cells. J. Lab. Clin. Med. 55: 663.

14. St. George, S., M. Friedman, and S. O. Byers. 1954.

- Mass separation of reticuloendothelial and parenchymal cells of rat's liver. Science. 120: 463.

15. Krueger, R. C., I. Melnick, and J. R. Klein. 1956. Formation of heme by broken cell preparations of duck erythrocytes. Arch. Biochem. Biophys. 64: 302; Goldberg, A., H. Asherbrucker, G. E. Cartwright, and M. M. Wintrobe. 1956. Studies on the biosynthesis of heme in vitro by avian erythrocytes. Blood. 11: 821 .

16. Kovach, J. S., P. A. Marks, E. S. Russell, and H. Epler. 1967. Erythroid cell development in mice; ultrastructural characteristics and hemoglobin synthesis. J. Mol. Biol. 25: 131.

17. Mazur, A., and E. Shorr. 1950. A quantitative immunochemical study of ferritin and its relation to the hepatic vasodepressor material. J. Biol. Chem. 182: 607.

18. Morell, H., J. C. Savoie, and I. M. London. 1958. The biosynthesis of heme and the incorporation of glycine into globin in rabbit bone marrow in vitro. J. Biol. Chem. 233: 923.

19. Greengard, O., and G. Acs. 1962. The effect of actinomycin on the substrate and hormonal induction of liver enzymes. Biochim. Biophys. Acta. 61: 652; Reich, E. 1963. Biochemistry of actinomycins. Cancer Res. 23 : 1428 ; Williams-Ashman, H. G., L. Shutsung, R. L. Hancock, L. Jurkowitz, and D. A. Silverman. 1967. Testicular hormones and the synthesis of ribonucleic acids and proteins in the prostate gland. Rec. Progr. Hormone Res. 20: 247 ; Revel, M., H. H. Hiatt, and J.-P. Revel. 1965. Actinomycin D: an effect on rat liver homogenates unrelated to its action on RNA synthesis. Science. 146: 1311.

20. Mazur, A., A. Carleton, and A. Carlsen. 1961. Relation of oxidative metabolism to the incorporation of plasma iron into ferritin in vivo. J. Biol. Chem. 236: 1109. Mazur, A., S. Green, and A. Carleton. 1960. Mechanism of plasma iron incorporation into hepatic ferritin. J. Biol. Chem. 235: 595.

21. Hevesy, G., and D. Lockner. 1962. Iron metabolism in health and in the neoplastic state. Arkiv. Kemi. 19: 303.

22. Miller, A., R. B. Chodos, C. P. Emerson, and J. F. Ross. 1956. Studies of the anemia and iron metabolism in cancer. J. Clin. Invest. 35: 1248.

23. Gross, H., M. Sandberg, and O. M. Holby. 1942. Changes in copper and iron retention in chronic diseases accompanied by secondary anemia. II. Changes in liver, spleen and stomach. Am. J. Med. Sci. 204: 201.

24. Neuberger, A., and J. S. F. Niven. 1951. Hemoglobin formation in rabbits. J. Physiol. 112: 292.

25. Jordan, H. E. 1942. Extramedullary blood production. Physiol. Rev. 22: 375 